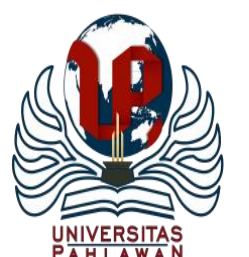

Jurnal Abdidas Volume 2 Nomor 6 Tahun 2021 Halaman 1463 - 1466

JURNAL ABDIDAS

http://abdidas.org/index.php/abdidas

\title{
Peran Tenaga Kesehatan dalam Memberikan Bimbingan Teknik Menyusui Disertai Pemberian Aroma Terapi Pada Ibu Postpartum di BPM Wilayah Kerja Puskesmas Air Dingin Kota Padang
}

\author{
Fatmi Nirmala Sari ${ }^{1 \bowtie}$, Binarni Suhertusi ${ }^{2}$ \\ Kebidanan, STIKes Alifah Padang, Indonesia ${ }^{1,2}$ \\ E-mail : fatmi.nirmala@gmail.com suhertusibinarni@yahoo.com
}

\begin{abstract}
Abstrak
Teknik menyusui merupakan hal yang penting dalam memulai proses menyusui. Ibu memerlukan pendampingan dari tenaga kesehatan maupun orang yang terdekat disekitarnya agar dapat membantu ibu memulai proses menyusui dengan benar. Melalui kegiatan ini, pengetahuan ibu tentang teknik menyusui dan pentingnya ASI Ekslusif bagi bayi/balita bertambah. Sehingga bisa meningkatkan angka ASI Ekslusif, khususnya di wilayah kerja Puskesmas Air Dingin. tujuan kegiatan Pengabdian kepada Masyarakat adalah memberikanedukasi kepada Ibu post partum dan suami/keluarga tentang manfaat bimbingan teknik menyusui, megajarkan teknik menyusui pada ibu postpartum dan mencegah terjadinya perdarahan pada postpartum. Melalui kegiatan ini, terjadi peingkatkan pengetahuan ibu mengenai pentingnya ASI Ekslusi serta teknik menyusui yang baik dan benar serta berpotensi meningkatkan angka ASI Ekslusif, khususnya di wilayah kerja Puskesmas Air Dingin Padang.
\end{abstract}

Kata kunci: teknik menyusui, ASI ekslusif, ibu postpartum

\begin{abstract}
Breastfeeding technique is important in starting the breastfeeding process. Mothers need assistance from health workers and those closest to them so that they can help mothers start the breastfeeding process properly. Through this activity, mothers' knowledge of breastfeeding techniques and the importance of exclusive breastfeeding for infants/toddlers increases. So that it can increase the number of exclusive breastfeeding, especially in the work area of the Air Cold Health Center. The purpose of Community Service activities is to provide education to postpartum mothers and their husbands/families about the benefits of breastfeeding technique guidance, teach breastfeeding techniques to postpartum mothers and prevent postpartum hemorrhage. Through this activity, there was an increase in mother's knowledge about the importance of exclusive breastfeeding and good and correct breastfeeding techniques and the potential to increase the rate of exclusive breastfeeding, especially in the work area of the Padang Air Cold Health Center.
\end{abstract}

Keywords: breastfeeding technique, exclusive breastfeeding, postpartum mother

Copyright (c) 2021 Fatmi Nirmala Sari, Binarni Suhertusi

\begin{tabular}{l}
\hline Corresponding author \\
Address
\end{tabular}

ISSN 2721-9224 (Media Cetak)

ISSN 2721- 9216 (Media Online) 
1463 Peran Tenaga Kesehatan dalam Memberikan Bimbingan Teknik Menyusui Disertai Pemberian Aroma Terapi Pada Ibu Postpartum di BPM Wilayah Kerja Puskesmas Air Dingin Kota Padang - Fatmi Nirmala Sari, Binarni Suhertusi

DOI: https://doi.org/10.31004/abdidas.v2i6.540

\section{PENDAHULUAN}

WHO tahun 2006 dalam Roesli 2010, mengeluarkan Standar Pertumbuhan Anak yang menegaskan pentingnya pemberian ASI saja kepada bayi sejak lahir sampai usia 6 bulan. Setelah itu, baru boleh diberikan makanan pendamping sambil tetap diberi ASI hingga usianya mencapai 2 tahun.

ASI mengandung berbagai nutrien yang diperlukan untuk tumbuh kembang bayi. Disamping itu ASI mengandung zat antibodi yang melindungi bayi terhadap penyakit dan kematian akibat penyakit infeksi yang umum ditemui pada tahun pertama kehidupan (Roesli, 2010). Berdasarkan Profil kesehatan Indonesia tahun 2019 cakupan pemberian ASI di Indonesia hanya $67,74 \%$. Sementara untuk Provinsi Sumatera Barat persentase pemberian ASI Eksklusif adalah 75,92 \% (Kemenkes RI, 2019).

Masalah yang paling sering dialami oleh ibu menyusui adalah puting susu lecet. Sekitar $57,4 \%$ ibu yang menyusui mengalami putting lecet disertai nyeri dan paling banyak dialami oleh ibu primipara sebanyak 54,9\%. Masalah puting susu lecet ini $95 \%$ terjadi pada wanita yang menyusui bayinya dengan posisi yang tidak benar. Kesalahan dari teknik menyusui dikarenakan posisi bayi yang menyusu tidak sampai areola hanya pada puting susu saja. Kesalahan lain juga bisa disebabkan saat ibu menghentikan proses menyusui kurang hatihati. Menurut penelitian yang dilakukan oleh Rinata \& Iflahah (2015) tentang “Teknik Menyusui Yang Benar Ditinjau Dari Usia Ibu, Paritas, Usia Gestasi Dan Berat Badan Lahir Di
RSUD Sidoarjo" terdapat 53, 3\% ibu yang yang masih salah dalam hal teknik menyusui.

Penggunaan Aroma terapi diharapkan dapat membantu ibu post partum untuk meningkatkan relaksasi dan kenyamanan sehingga diharapkan produksi ASI dapat meningkat yang dapat memicu kontraksi uterus. Lavender merupakan salah satu minyak esensial yang populer dan secara luas digunakan dalam bidang kesehatan klinis khususnya mengatasi permasalahan psikosomatik dalam

Berdasarkan Analisis Masalah di atas maka rumusan masalah adalah" Bagaimana memberikan bimbingan teknik menyusui yang benar disertai dengan pemberian aroma terapi pada ibu Post Partum. ginekologi Matsumoto, 2013).

Solusi permasalahan yang akan diberikan adalah Pemberian bimbingan teknik menyusui pada ibu postpartum dengan melibatkan suami/keluarga di BPM Wilayah Kerja Puskesmas Air Dingin Kota Padang. Sebelumnya diberikan edukasi tentang teknik menyusui kepada ibu postpartum dan suami/ keluarga melalui penyuluhan yang disampaikan oleh mahasiswa dan dosen Stikes Alifah Padang. Setelah dilakukan penyuluhan, dilakukan simulasi pada ibu postpartum dengan melakukan teknik menyusui yang benar.

Adapun tujuan kegiatan Pengabdian kepada Masyarakat adalah memberikanedukasi kepada Ibu post partum dan suami/keluarga tentang manfaat bimbingan teknik menyusui, megajarkan teknik menyusui pada ibu postpartum dan mencegah terjadinya perdarahan pada postpartum 
1464 Peran Tenaga Kesehatan dalam Memberikan Bimbingan Teknik Menyusui Disertai Pemberian Aroma Terapi Pada Ibu Postpartum di BPM Wilayah Kerja Puskesmas Air Dingin Kota Padang - Fatmi Nirmala Sari, Binarni Suhertusi

DOI: https://doi.org/10.31004/abdidas.v2i6.540

\section{METODE}

Kegiatan pengabdian masyarakat dilaksanakan dengan melakukan bimbingan teknik menyusui pada ibu postpartum dengan melibatkan suami/keluarga di BPM Wilayah Kerja Puskesmas Air Dingin Kota Padang. Sebelumnya diberikan edukasi tentang teknik menyusui kepada ibu postpartum melalui penyuluhan yang disampaikan oleh tim pengabdian bersama dengan bidan. Setelah dilakukan penyuluhan, dilakukan simulasi pada ibu postpartum dengan melakukanteknik menyusui yang benar.

Peserta ibu post partum di BPM Wilayah kerja Puskesmas Air Dingin Kota Padang sebanyak lebih kurang 50 orang. Pengabmas ini dilakukan pada bulan Desember 2020 sampai dengan Februari 2021 di BPM Wilayah Kerja Puskesmas Air Dingin. BPM yang dilakukan pengabmas juga ikut serta dalam memberikan bimbingan teknik menyusui kepada ibu post partum.

\section{HASIL DAN PEMBAHASAN}

Kegiatan ini dilaksanakan di PMB yang berada di wilayah kerja Puskesmas Air Dingin Kota Padang. Kegiatan ini diawali kunjungan ke beberapa lokasi praktek bidan mandiri di wilayah kerja Puskesmas Air Dingin Kota Padang. Kunjungan dilakukan dalam rangka penyampaian tujuan kegiatan, persamaan persepsi dan kerjasama dengan mitra. Hasil dari diskusi bersama mitra, diperoleh kesimpulan perlu adanya edukasi tentang teknik menyusui yang baik dan benar kepada ibu. Oleh karena itu, tim pengabdian bekerja sama dengan mitra dan melaksanakan kegiatan penyuluhan untuk memberikan edukasi teknik menyusui pada ibu.

Teknik menyusui merupakan hal yang penting dalam memulai proses menyusui. Pada minggu pertama persalinan ibu mengalami fase dimana mengakibatkan ibu lebih sensitif, ibu memerlukan pendampingan dari tenaga kesehatan maupun orang yang terdekat disekitarnya agar dapat membantu ibu memulai proses menyusui dengan benar (Ilmiasih, 2017).

Kegiatan dilakukan di tempat praktek mandiri bidan. Adapun edukasi yang berikan kepada ibu meliputi pentingnya teknik menyusui yang baik dan benar. Ibu harus mengetahui apakah bayi menyusui secara efektif atau tidak, ibu juga harus mengetahui bagaimana cara menyusui yang benar. Teknik Menyusui yang benaryang dilakukanoleh ibuadalah cara memberikan ASIkepada bayi dengan perlekatan dan posisi ibu dan bayi denganbenar.

Fungsi dan tujuan pemberian ASI adalah karena ASI mengandung banyak nutrisi yang paling sesuai bagi kebutuhan tubuh bayi, serta mudah diterima dan dicerna oleh sistem pencernaannya yang masih sangat rentan. Jika diberi makanan tambahan lain sebelum bayi berusia 6 bulan, maka pencernaan bayi belum mampu mencerna dengan baik makanan tersebut, bahkan risikomunculnya penyakit pencernaan akan lebih besar. Setelah bayi berusia di atas 6 bulan, mak anan tambahan pun boleh diberikan secara bertahap sesuai perkembangan sistem pencernaan bayi, sampai 
1465 Peran Tenaga Kesehatan dalam Memberikan Bimbingan Teknik Menyusui Disertai Pemberian Aroma Terapi Pada Ibu Postpartum di BPM Wilayah Kerja Puskesmas Air Dingin Kota Padang - Fatmi Nirmala Sari, Binarni Suhertusi

DOI: https://doi.org/10.31004/abdidas.v2i6.540

usia 2 tahun saat ia sudah bisa makan makanan normal seperti yang dikonsumsi orang dewasa.

Menyusui juga membantu ibu dan bayi membentuk ikatan tali kasih yang kuat. Pengetahuan ibu yang baik mengenai ASI dan bekerja, persiapan ibu yang baik menjelang dan saat bekerja, pengetahuan memerah ASI, penyimpanan dan pemberiannya, dukungan keluarga serta dukungan tempat kerja memberikan dampak yang besar bagi keberhasilan ibu menyusui (Suradi, Rulina. 2010).

Bila ibu memahami cara yang benar meletakkan bayinya pada posisi yang benar ketika menyusui, memahami pula waktu yang diinginkan oleh bayinya untuk menyusu, akan membuat ibu percaya diri karena mampu melakukan yang benar dalam memberikan ASI, maka berbagai hal yang menyulitkan (faktor penyulit) yang sifatnya umum, dapat dihindari atau dicegah. Oleh karena itu, disinilah letak salah satu dari peran bidan dalam mendukung pemberian ASI (Suherni. 2009)

Kegiatan ini juga melibatkan bidan selaku tenaga kesehatan dan juga suami/keluarga. Gerakan sadar menyusui justru sering terhadang kendala orang terdekat, entah suami atau keluarga. Sehingga tim pengabdi melibatkan suami/keluarga untuk diberikan informasi pentingnya bayi mendapatkan ASI Ekslusif. Keterlibatan suami/keluarga ini diharapkan bisa meingkatkan dukungan orang terdekat sehingga dapat meningkatkan kemauan dan semangat ibu untuk menyusui bayinya.
Peran bidan juga cukup sentral dalam mensosialisasikan pemberian ASI eksklusif ini. Sebagai bagian dari tenaga kesehatan, bidan diwajibkan memberikan pemahaman tentang pemberian ASI eksklusif tersebut. Peran bidan terhadap pemberian ASI eksklusif ini sangat penting tidak hanya bagi bayi tetapi juga bagi ibu yang menyusui (Depkes RI, 2005).

Dukungan bidan dalam pemberian ASI dapat mencegah atau menghindari berbagai kesulitan umum dalam pemberian ASI eksklusif. Peranan awal bidan dalam mendukung pemberian ASI eksklusif dapat diberikan dengan meyakinkan ibu bahwa bayi memperoleh makanan yang mencukupi dari payudara ibunya serta membantu ibu sedemikian rupa sehingga ia mampu menyusui bayinya sendiri (Suherni, 2009). Dukungan bidan dalam mensosialisasikan ASI dapat dimulai sejak kehamilan terjadi. Setidaknya ibu hamil mengikuti 2 kali kelas antenatal yang menjelaskan keuntungan ASI dan bagaimana cara sukses menyusui saat kelahiran terjadi. Mempersiapkan ibu hamil yang kelak akan menyusui mempengaruhi keberhasilan menyusui. Edukasi mengenai pentingnya air susu ibu harus didapatkan oleh setiap ibu hamil sebelum kelahiran terjadi (Suradi, Rulina, dkk. 2010).

Peserta mengikuti kegiatan penyuluhan dengan antusias. Beberapa ibu diberikan kesempatan bertanya dan diberikan penjelasan ulang dan lebih detail oleh tim pengabdi dan bidan untuk meningkatkan pengetahuan ibu. Kegiatan ini 
1466 Peran Tenaga Kesehatan dalam Memberikan Bimbingan Teknik Menyusui Disertai Pemberian Aroma Terapi Pada Ibu Postpartum di BPM Wilayah Kerja Puskesmas Air Dingin Kota Padang - Fatmi Nirmala Sari, Binarni Suhertusi

DOI: https://doi.org/10.31004/abdidas.v2i6.540

diakhiri dengan pemberian aroma terapi kepada ibu/peserta.

Melalui kegiatan ini, meningkatkan pengetahuan ibu mengenai pentingnya ASI Ekslusi serta teknik menyusui yang baik dan benar. Sehingga tim pengabdi dapat berharap bisa meningkatkan angka ASI Ekslusif, khususnya di wilayah kerja Puskesmas Air Dingin.

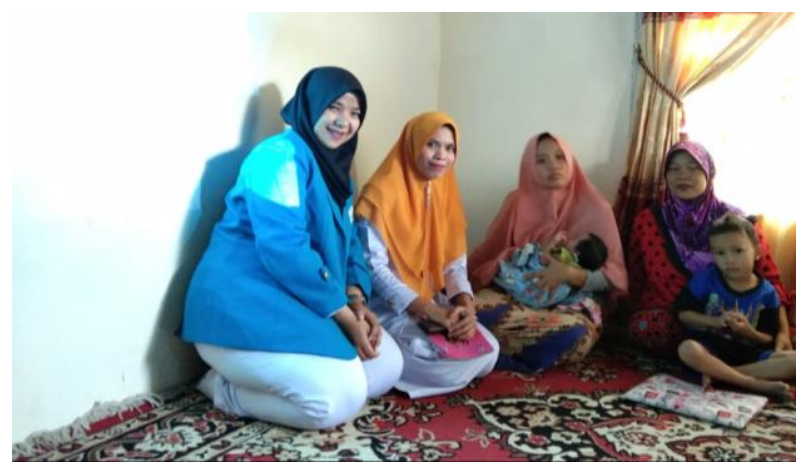

Gambar 1. Dokumentasi Kegiatan

\section{SIMPULAN}

Teknik menyusui merupakan hal yang penting dalam memulai proses menyusui. Bila ibu memahami cara yang benar meletakkan bayinya pada posisi yang benar ketika menyusui, memahami pula waktu yang diinginkan oleh bayinya untuk menyusu, akan membuat ibu percaya diri karena mampu melakukan yang benar dalam memberikan ASI. Ibu memerlukan pendampingan dari tenaga kesehatan maupun orang yang terdekat disekitarnya agar dapat membantu ibu memulai proses menyusui dengan benar. Melalui kegiatan ini, pengetahuan ibu tentang teknik menyusui dan pentingnya ASI Ekslusif bagi bayi/balita bertambah. Sehingga bisa meningkatkan angka ASI Ekslusif, khususnya di wilayah kerja Puskesmas Air Dingin.

\section{DAFTAR PUSTAKA}

Maritalia, D. (2012). Asuhan Kebidanan Nifas Dan Menyusui. Yogyakarta : Pustaka Pelajar.

Perinasia. (2004). Bahan Bacaan Manajemen Laktasi. Jakarta: Perkumpulan Perinatologi Indonesia

Roesli, U. (2005). Mengenal ASI Eksklusif. Jakarta: Trubus Agriwidia

Dewi, V.N.L \& Tri, S. (2011). Asuhan Kebidanan pada Ibu Nifas. Jakarta Salemba Medika

Rinata E, Rusdyati T, Sari PA. (2016). Teknik Menyusui Posisi, Perlekatan dan Keefektifan Menghisap-Studi pada Ibu Menyusui di RSUD Sidoarjo. In: Prosiding Seminar Nasional \& Internasional.

Risneni R. Hubungan Teknik Menyusui Dengan Terjadinya (2017). Lecet Puting Susu Pada Ibu Nifas. J Keperawatan. 11(2):158-63.

Hardiana H. (2018). Hubungan Pengetahuan Ibu Dengan Cara Menyusui Yang Benar Pada Bayi Usia 0-6 Bulan Di Wilayah Kerja Puskesmas Muara Bungo I Kabupaten Bungo Tahun 2017. J Ilm Univ Batanghari Jambi. 18(1):189-94.

Meylana, N. (2012). Efektivitas Akupresur Dan Aromaterapi Lavender Terhadap Insomnia Pada Wanita Perimenopause Di Desa Pancuranmas Magelang. 28-37.

Tuti Widyawati, \& Nurul, M. (2018). Literatur Review : Pijat Oksitosin Dan Aroma Terapi Lavender Meningkatkan Produksi Asi. Jurnal Kebidanan, 8(1), 44-55 